\begin{tabular}{|c|c|}
\hline$\Delta N$ & Article History \\
\hline ahel J. Vet. Sci. Vol. 18, No. 3, pp 8-18 (2021) & Received: 30-11-2020 \\
\hline pyright (C) 2021 Faculty of Veterinary Medicine, University of Maiduguri & Revised: 18-08-2021 \\
\hline hts reserved & $\begin{array}{l}\text { Accepted: 18-08-2021 } \\
\text { Published. } 30-09-2021\end{array}$ \\
\hline
\end{tabular}

\title{
Assessment of Biosecurity Measures and Distribution of Daily Live Bird Markets in Four North-Western States of Nigeria
}

\author{
${ }^{1}$ Hassan, S. A., ${ }^{2}$ Maikai, B. V., ${ }^{2}$ Kabir, J. and ${ }^{2 *}$ Aliyu, M. B. \\ ${ }^{1}$ Kano State Ministry of Agriculture and Natural Resources, Kano, Nigeria \\ ${ }^{2}$ Department of Veterinary Public Health and Preventive Medicine, Faculty of Veterinary Medicine, Ahmadu Bello University, Zaria, Kaduna \\ State, Nigeria.
}

*Author for Correspondence: mbaliyu@abu.edu.ng

\begin{abstract}
Maintenance of strict biosecurity measures is essential in preventing disease spread from Live Bird Markets (LBMs) which serve as a major intermingling area for poultry from different sources. This study assessed the Biosecurity measures and spatial distribution of daily Live Bird Markets of four North-western States in Nigeria. Closed ended questionnaires were administered in 35 daily LBMs in Kaduna, Kano, Katsina and Zamfara states and identification of disinfectants used in the LBMs were noted. Swab samples of birds' cages in the LBMs were taken for $E$. coli isolation. The live bird managers and marketers were all male $(100 \%)$ across all the four states. Only $6(17 \%)$ out of the 35 LBMs had high biosecurity level, $69 \%$ had a moderate biosecurity level and 5(14\%) were graded as low. Of the 400 Live bird marketers administered questionnaires, only 71 (18\%) employ good biosecurity practices and 305(76\%) were graded as fair and remaining 24(6\%) as poor. Majority of the LBMs were located within human settlements without any form of barrier. There were seven main types of disinfectants identified across the all LBMs. Esherichia coli was isolated from 1(17\%) LBM among the 6(17\%) LBMs that were identified to have and use disinfectant. From the remaining $29(83 \%)$ LBMs, E. coli was isolated from only $5(17 \%)$ despite lacking in use of disinfectant by these LBMs. Live bird marketers should be educated on the need to adhere to biosecurity measures and practices.
\end{abstract}

Keywords: Biosecurity, Distribution, Live bird markets, Disinfectants, North-western Nigeria

\section{INTRODUCTION}

Domestic chickens (Gallus gallus domesticus) are a major source of animal proteins for human. Chickens were primarily domesticated from the red jungle fowl (Gallus gallus gallus), a bird that still runs wild in most of Southeast Asia (Qanbari et al., 2019). Poultry meat and egg are excellent sources of protein, and are relatively cheap hence their high demand globally. Most countries are trying to meet the demand for these products both locally and internationally (David, 2015). According to Pagani et al. (2008) poultry production is divided into four sectors: Industrial integrated system; Commercial production system; Small-scale commercial production system; and Village or backyard system, based on level of production. In developed countries, poultry from all the four sectors may be taken to live bird markets from where they are sold to the final consumers. In developing countries, poultry in the live bird markets (LBMs) are mainly from the small-scale commercial production system and village or backyard system, and occasionally from the commercial production system (Pagani et al., 2008). The LBMs are essential for sales of poultry in many developing countries, and they are a preferred place for many people to purchase poultry for consumption throughout the world (Cardona et al., 2009). Live Bird Markets worldwide serve as the most important mixing point of all birds, and for the maintenance and transmission of poultry diseases (Olubunmi et al., 2017). Several studies have linked human infection/outbreaks of influenza to LBMs (FAO, 2015; FAO, 2018).

Biosecurity measures such as introduction of rest days, segregation of birds, cleaning and disinfection have been shown to significantly reduce the circulation of infection in the LBMs (FAO, 2008). Biosecurity requires the adoption of a set of attitudes and behaviours by people to reduce risk in all activities involving domestic, captive exotic, wild birds and their products (FAO, 2008). According to the FAO (2008) the three fundamental basic principles of biosecurity are segregation, cleaning and disinfection. Segregation is the creation and maintenance of barriers to limit the potential opportunities for infected animals and contaminated materials to enter an uninfected site. This step, when properly applied, may prevent most infection (FAO, 2008). Materials like vehicle and equipment that have to enter (or leave) a site 
must be thoroughly cleaned to remove visible dirt. This will remove most of the pathogen that is contaminating the materials (FAO, 2008). Properly applied disinfection will inactivate any virus that is present on materials that have already been thoroughly cleaned. Cleaning precedes disinfecting on surfaces, especially those with visible contamination, and helps to ensure the effectiveness of the subsequent disinfection step (Margaret and Paul, 2015).

The growth and development of the poultry industry in Nigeria are being threatened by outbreaks of infectious diseases causing high mortality and huge economic losses (Augustine et al., 2010). There is a high prevalence of poultry diseases in Nigeria including zoonotic diseases, which raises concern about the quality and safety of poultry slaughtered for human consumption (Solomon et al., 2012). The LBMs play a major role in the maintenance of infection as they are never empty of birds, allowing pathogens to persist and accumulate over time turning the markets into heavily contaminated sites (FAO, 2008). Daily LBMs operate seven days a week with no provision for resting days which consequently favours the persistence of infection in these markets. In Nigeria, $90 \%$ of poultry marketing is by live sales with less than $2 \%$ being processed or frozen chickens (Muhammed, 2008).

In Nigeria, before the outbreak of HPAI in 2006, the poultry population was estimated at around 150 million, with a large majority of local chickens and a minority of exotic breeds (Pagani et al., 2008). According to National Bureau for Statistics (2019), poultry consumption in the Northwest accounts for $19.8 \%$ (more than 174 billion naira) of total national expenditure on poultry and poultry products. Live bird markets in Nigeria are generally located in specific areas of general markets (Pagani et al., 2008). Daily LBMs are generally located in urban and semi-urban areas and receive poultry from the surrounding weekly markets and from the larger poultry industry (Pagani et al., 2008).

Many people visit live bird markets in Nigeria with the LBMs having the potential to harbour many different types of disease organisms and serving as a likely source of spread of zoonotic diseases. Information generated from the study can be used for training of operators of LBMs by the relevant authorities. The aim of the study was to determine the distribution of LBMs and assess their present biosecurity measures in four North-western states of Nigeria and also to identify all the type(s) of disinfectant(s) used in the LBMs.

\section{MATERIAL AND METHODS}

\section{Study Area}

The study was conducted at the daily live bird markets in some North-western states of Nigeria. Northwest is one of the six geopolitical zones in Nigeria and consists of seven (7) states which are Jigawa, Kaduna, Kano, Katsina, Kebbi, Sokoto, Zamfara states and covers a total land area of about $213,976 \mathrm{~km}$. The zone is bordered to the north by Niger republic; to the south by Niger and Nasarawa states; Plateau, Bauchi and Yobe states to the east, and by Benin republic to the west. Four states (Kaduna, Kano, Katsina and Zamfara) were randomly selected from the seven North-western states.

\section{Determination of Geo-references of Live Bird Markets}

Geographic co-ordinates of each of the LBMs was taken using Hand held GPS and transferred into spreadsheet (Microsoft excel). Spot maps were plotted using Epi-info7 by importing the data from the spreadsheet.

\section{Study Design}

A cross-sectional study, divided into surveys 1 and 2. Both involve the administration of closed-end structured questionnaires to managers and marketers. The inclusion criteria were daily LBMs in pre-selected states and located within the state metropolis. Also, only managers willing to give disinfectant samples and marketers with cages were considered.

Each of the managers was administered a closed ended questionnaire. Since the LBMs identified were 35 in number, the number of questionnaires administered to the managers was therefore 35 . Identification of disinfectant from managers was done based on availability of the disinfectant.

A second questionnaire was also administered to every cage owner (marketer) and swab sample of the cage was taken. The sample size for cage swab samples was determined using the formula by Thrusfield (2005), whereby a prevalence rate of $56 \%$ was used from a study on number of marketers that were reported to be using disinfectant (Pagani et al., 2008). The sample size from the formula was 379 , but $5.5 \%$ of the calculated sample size was added to minimize loss due to sampling error. Hence, 400 cage swab samples were collected from the birds' cages of the marketers after responding to the questionnaire.

The questionnaires were prepared in English language and where necessary the questions were interpreted in Hausa language to ensure accuracy. The questionnaires were administered by face-to-face interview.

The questionnaires administered to managers include questions addressing the demographic characteristics of the managers and assessment of biosecurity level and facilities in the market. The questionnaire assessed biosecurity measures in the LBMs based on three broad areas as described by Awosanya (2015) who measured biosecurity on Pig farms, also adapted from an earlier study by Barcelo and Marco (1998). Both categorized the biosecurity compliance into 3 thematic areas which are location, isolation and quarantine of replacement stock and conditions of the farm. For our study, the three areas used were location, isolation and condition of the LBM. For location, one variable was considered which was fencing. For isolation, three variables were considered namely separation from other LBMs, sighting of wild birds and presence of rodents. For condition of the LBMs, five variables were considered which were drainage facilities, adequate garbage disposal, availability of clean water, whether floors and walls are easy to clean and what is used in cleaning. Number of questionnaires administered to the managers was based on the number of LBMs tested with one questionnaire per LBM (35).

A second questionnaire was administered to selected live bird marketers. They were selected based on willingness to allow 
for collection of samples. The questions asked were addressing demographic characteristics of the marketers and their specific level of biosecurity practices. It was designed to assess biosecurity practices of the marketers based on 6 variables which include; what material the cages are made of, cleaning of cages, what is used in cleaning cages, if they quarantine sick birds, how dead birds are disposed of and whether other species of birds are being sold.

\section{Sample Collection}

The number of swab sample taken from each state was calculated by proportionate sampling from which Kaduna (with 12 LBMs) $=137(34.3 \%$ ), Kano (15) $=171(42.5 \%$ ), Katsina $(4)=46(11.5 \%)$ and Zamfara $(4)=46(11.5 \%)$. The number of samples from individual LBMs identified were collected based on convenience and availability.

\section{Data Management and Interpretation}

A modified scoring system was developed for all the variables from that described by Awosanya (2015). Yes was scored as 1 , while No was scored as 0 for all the variables based on the protective or risk effect of such variable. For instance, presence of fence around the LBM is scored as 1 while its absence is 0 . For 'drainage facilities', both fair and good are scored as 1 , and poor as 0 . And for 'what is used for cleaning', use of water alone is scored as 0 and 1 when detergent or disinfectant is used.

A total score of 9 and 6 is obtainable for the $1^{\text {st }}$ and $2^{\text {nd }}$ questionnaires respectively, and the higher the score, the more indication of a better biosecurity level. For the $1^{\text {st }}$ questionnaire, a score of 7 and above is considered 'high', score between 4 and 6 is moderate, and 3 or below is considered low. For the $2^{\text {nd }}$ questionnaire, 1 and 2 is considered poor, 3 and 4 as fair and 5 and 6 as good biosecurity practices.

\section{Surface Swab Sample Collection and Isolation of $\boldsymbol{E}$. coli}

Swab samples of bird cages (a single swab from each marketer) of about $10 \mathrm{~cm}^{2}$ of the innermost area of the floor of the birds' cages were collected using a sterile swab stick. The sticks were then immersed in bottles containing the transport medium ( $5 \mathrm{ml}$ buffered peptone), maintained in a cold chain and transported to the Bacteria laboratory of the Department of Veterinary Public Health and Preventive Medicine, Ahmadu Bello University, Zaria from which $E$. coli was isolated.

One $\mathrm{ml}$ of the sample was taken and added to $9 \mathrm{ml}$ of Tryptone soya broth as enrichment and incubated for 24hours. This was then plated on a selective media (EMB) and incubated for 24hours as first described by Apostolakos et al. (2020). Suspected positive samples (with characteristic greenish metallic sheen on $E$. coli) were transferred into nutrient broth in sterile sample bottles and afterwards subjected to conventional biochemical and kit (Microbact ${ }^{\mathrm{TM}}$ ) tests.

\section{Documenting Types of Disinfectants Used}

A form containing information about the disinfectants and their usage (such as the type of disinfectant used, trade name, chemical content and dilution instructions amongst others) was also filled accordingly.

\section{Conventional Biochemical Tests}

Indole, Methyl red, Voges-proskauer, Citrate (IMViC), Urease, Motility, Triple sugar iron and Sugars (Glucose, inositol, lactose, mannitol, sorbitol) were carried out to further confirm the organism as E. coli as described by Cheesbrough (1981).

\section{Kit (Microbact ${ }^{\mathrm{TM}}$ ) Biochemical Test}

Oxoid Microbact ${ }^{\mathrm{TM}}$ 12A/12E identification kit was used to identify the isolates according to manufacturer instruction.

One to three colonies from a $24 \mathrm{hrs}$ culture were emulsified in saline. The test strip was placed in a holding tray and the seal was peeled back. 4 drops of the bacterial suspension were placed into each well and followed by 2 drops of mineral oil in the black wells. The seal was then replaced and incubated at $35^{\circ} \mathrm{C}$ for 24 hours.

In well 8, 2 drops of indole reagent is added and read after 2 mins. In 10, a drop of VP1 followed by VP2 was added and read after 15 mins. And into well 12, a drop of TDA was added and read immediately.

The Results were entered into Oxoid Microbact ${ }^{\mathrm{TM}}$ Identification Chart where the substrates were organized into 4 set of three reactions with each substrate assigned a numerical value (1,2 or 4$)$. The sum of the positive reactions for each triplet forms a single digit referred to as Octal code. The codes were entered into Microgen ID version 1.2 software which generated a report of percentage probability of the likely organism.

\section{Data Analysis}

Data generated from administered questionnaires were entered into Epi-info 7 and later exported to Statistical Package for Social Sciences (SPSS) version 20.0 for analysis. Categorical variables were evaluated using Fisher's exact test for association. $\mathrm{P}$ values $\leq 0.05$ were considered significant.

\section{RESULTS}

\section{Geo-spatial Distribution of the LBMs}

Figure 1 shows the distribution of the LBMs within the region with the numbers denoting the LBMs sampled within the states. Spot maps of live bird markets in Kaduna (Figure 2) and Kano (Figure 3) shows that they are well distributed within the metropolitan areas. That of Katsina (Figure 4) shows that the LBMs are sparsely distributed, and Figure 5 shows that the LBMs in Zamfara are concentrated within an area. Most of the LBMs are located within human settlements without any form of barrier.

\section{Demographic Characteristics of the Live Bird Market Managers and Marketers}

All the $35(100 \%)$ managers were males. None of the managers was below the age of 20years, while $21(60 \%)$ of the managers were within the age group of 40-59 followed by $11(31.4 \%)$ between the age group of $20-39$. In terms of education, $9(25.7 \%)$ had non-formal education, $6(17.1 \%)$ 
were educated up to primary level and $4(11.4 \%)$ up to tertiary level. Majority, $16(45.7 \%)$ were secondary school leavers (Table 1).

All the 400 (100\%) live bird marketers administered questionnaire were males. Majority 219(54.8\%) were between the ages of 20-39 years, $142(25.5 \%)$ were between $40-59$ years, $32(8.0 \%)$ were $>60$ years, and $7(1.8 \%)$ were $<20$ years. One hundred and sixteen $(29.0 \%)$ had non-formal education, 65 (16.3\%) had primary education, $184(46.0 \%)$ had secondary education and $35(8.8 \%)$ had tertiary education (Table 2).

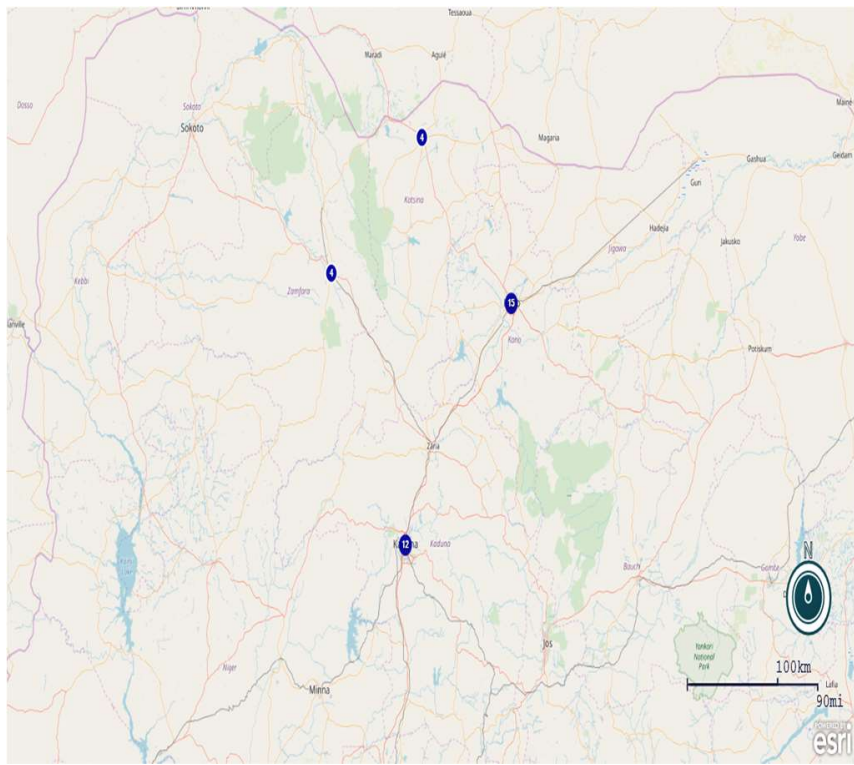

Figure 1: Metropolitan Daily LBMs distribution within the Northwestern Nigeria. (Blue dots on the map are indication of the LBMs) (EpiInfo, scale 100km)

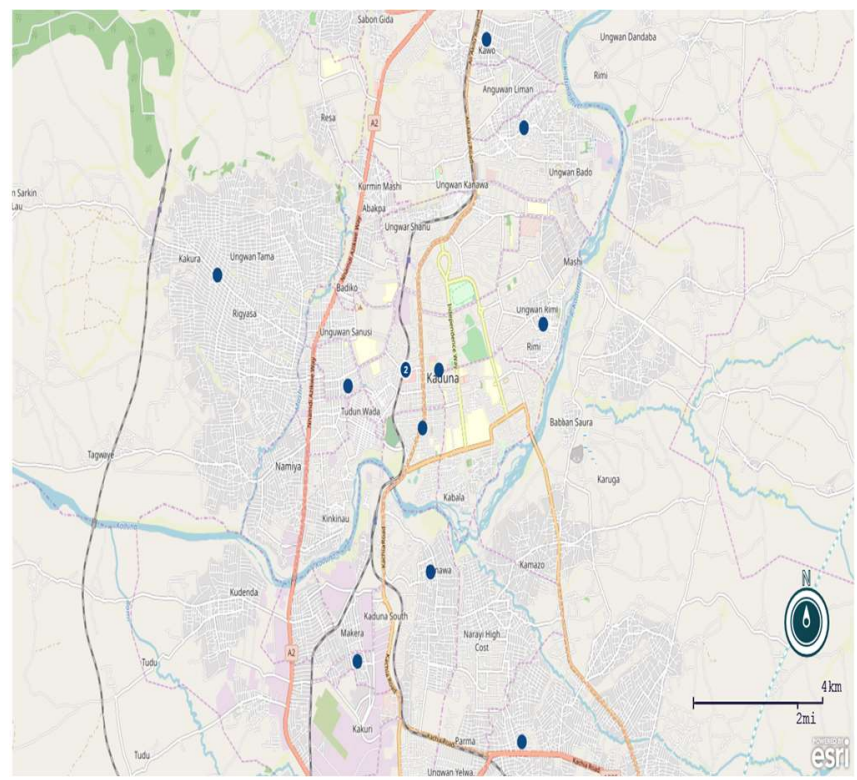

Figure 2: Distribution of Daily LBMs within Kaduna metropolis (Blue dots on the map are indication of the LBMs) (EpiInfo, scale $4 \mathrm{~km})$

\section{Biosecurity Measures/Practices in the Live Bird Markets}

Twenty-eight $(80.0 \%)$ out of the 35 LBMs had no fencing while the remaining $7(20.0 \%)$ were fenced. Only $7(20.0 \%)$ had good drainage system, 13 (37.1\%) had fairly good and the remaining $15(42.9 \%)$ had poor drainage system. Thirtytwo $(91.4 \%)$ of the LBMs have had reports of presence of rodents while $3(8.6 \%)$ have had no such report. Wild birds have been sighted in $3(91.4 \%)$ of the LBMs and none have been sighted in 32 (91.4\%) of the LBMs. There was provision for garbage disposal in $33(94.3 \%)$ of the LBMs whereas the remaining $2(5.7 \%)$ had no good garbage disposal system. Ten $(28.6 \%)$ of the LBMs had no source of water while 25 (71.4\%) had sources of water within the LBMs. In 17 (48.6\%) of the LBMs, the walls and floors of the processing area were tiled or cemented which facilitates cleaning while $18(51.4 \%)$ had no such provision.

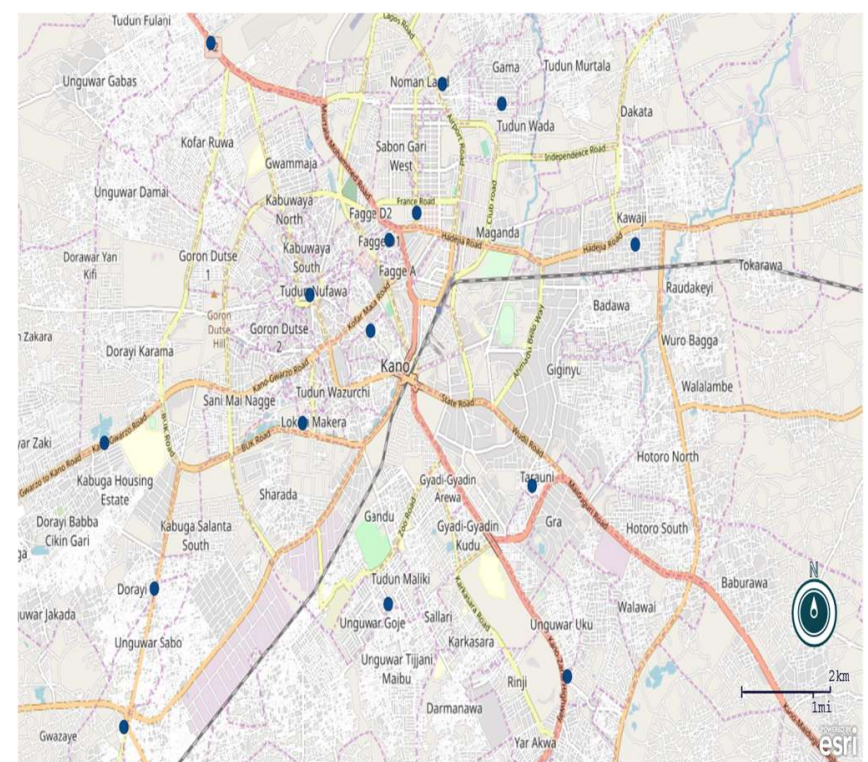

Figure 3: Distribution of Daily LBMs within Kano metropolis (Blue dots on the map are indication of the LBMs) (EpiInfo; scale $2 \mathrm{~km})$

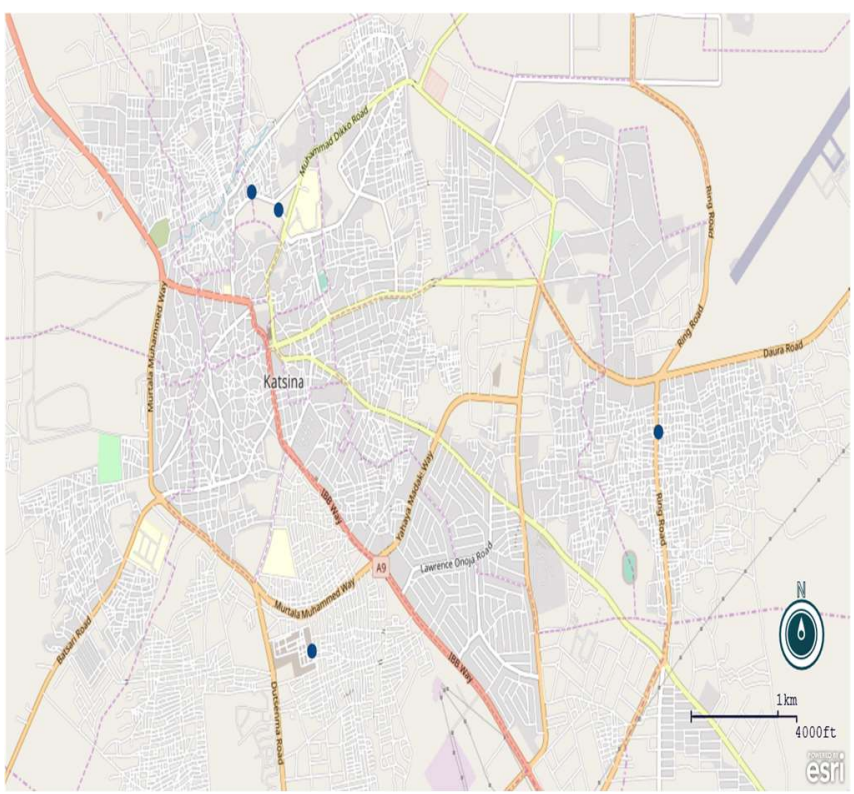

Figure 4: Distribution of Daily LBMs within Katsina metropolis (Blue dots on the map are indication of the LBMs) (EpiInfo, scale $1 \mathrm{~km})$

All the LBMs reportedly engage in daily cleaning of the processing area with $7(20.0 \%)$ using only water, $14(40.0 \%)$ 
using water and detergent, and the last 14 (40.0\%) using water, detergent and disinfectant. Three $(21.4 \%)$ out of the 14 that use water, detergent and disinfectant said they use more than one type of disinfectant while the remaining $11(78.6 \%)$ do not alternate disinfectants. All the managers said they enforce the practice of hand washing by the processors before and after processing of poultry but only $5(14.0 \%)$ enforce the practice of hands disinfection (Table 3). From the scoring system adopted, 6 of the LBMs had scores between 7 and 9 which were therefore graded as having high biosecurity measures. 24 had scores between 4 and 6 and 5 had scores between 1 and 3 and hence graded as having moderate and low biosecurity measures respectively (Table 4).

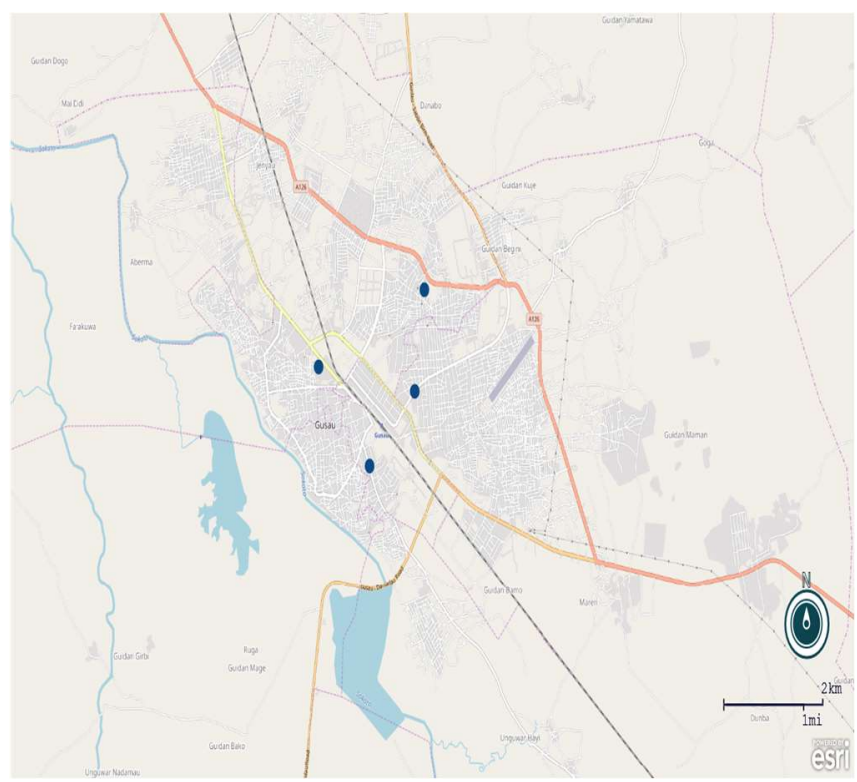

Figure 5: Distribution of Daily LBMs within Gusau metropolis (Blue dots on the map are indication of the LBMs) (EpiInfo, scale $2 \mathrm{~km})$

Of the 400 marketers sampled, only $73(18.3 \%)$ use metal cages, while the remaining $327(81.8 \%)$ use wooden cages. Almost all the marketers $399(99.8 \%)$ reportedly clean their cages. Only $1(0.3 \%)$ admitted to not cleaning his cage. Of those that do clean their cages, majority, $351(87.8 \%)$ only use broom to sweep the cages, $4(1.0 \%)$ use water, $16(4.0 \%)$ use water and detergent and $28(7.0 \%)$ use water, detergent and disinfectant. Majority 385 (96.3\%) of the marketers say they quarantine their birds when sick while the remaining 15 $(3.8 \%)$ say they do not. On safe disposal of dead birds, majority $357(89.3 \%)$ dispose of the birds by taking away from the market, $37(9.3 \%)$ by burning, $4(1.0 \%)$ by burying within the farm and $1(0.3 \%)$ said he disposes the dead birds by feeding to predators. Eighty-three (20.8\%) of the respondents admitted to selling other species of animals while 317 (79.3\%) sell only avian species. Summarily, 71 out of the 400 live bird marketers had scores between 5 and 6 and were graded as employing good biosecurity practices; 305 had scores between 3 and 4, and 24 had scores between 1 and 2 and were graded as employing fair and poor biosecurity practices respectively (Table 5).

\section{Isolation of Eschericia coli}

Out of the total 400 swab samples collected, 121 had the characteristic 'blue black colonies with greenish metallic sheen on Eosin-methylene Blue' following culture and isolation for E. coli. These were the suspect positives.

Following the MR/VP, Citrate, Urease, SIM and TSI tests, and the kit (Microbact ${ }^{\mathrm{TM}}$ ) tests on the 121 suspect positive samples, 7 samples were positive for E. coli. These were Urease negative, Citrate negative, Indole positive, Motile, Hydrogen sulfide negative, Methylene red positive and Voges proskauer negative, and showed percentage probability (of being E. coli) from the ID system of 97.11, 91.92, 84.29, 97.11, 97.11, 92.97 and $92.11 \%$ comprising of 1 from a LBM in Katsina, 2 from Kaduna and 4 from Kano.

From the 400 swab samples collected from cages of marketers for E. coli isolation, $121(30 \%)$ were positive on EMB, while $7(1.8 \%)$ were confirmed following biochemical test and microbacterial characterization.

Table 1: Demographic Characteristics of Live Bird Market Managers in North-western States of Nigeria

\begin{tabular}{lll}
\hline Variable & Frequency & Percentage \\
\hline Gender & 35 & 100 \\
Male & 0 & 0 \\
Female & & \\
Age & 0 & 0 \\
$\quad<20$ & 11 & 31.4 \\
$20-39$ & 21 & 60 \\
$40-59$ & 3 & 8.6 \\
$60>$ & & \\
Education & 9 & 25.7 \\
Non-formal & 6 & 17.1 \\
Primary & 16 & 45.7 \\
Secondary & 4 & 11.4 \\
Tertiary & & \\
\hline
\end{tabular}


Table 2: Demographic Characteristics of Live Bird Marketers in North-western Nigeria

\begin{tabular}{lll}
\hline Variable & Frequency & Percentage \\
\hline Gender & 400 & 100 \\
Male & 0 & 0 \\
Female & 7 & \\
Age & 219 & 1.8 \\
$<20$ & 142 & 54.8 \\
$20-39$ & 32 & 35.5 \\
$40-59$ & & 8.0 \\
$60>$ & 116 & 29.0 \\
Education & 65 & 16.3 \\
Non-formal & 184 & 46.0 \\
Primary & 35 & 8.8 \\
Secondary & & \\
Tertiary & & \\
\hline
\end{tabular}

Table 3: Biosecurity measures in Live Bird Markets of North-western States of Nigeria

\begin{tabular}{|c|c|c|c|c|c|c|}
\hline \multicolumn{7}{|c|}{ Frequency } \\
\hline Variable & Kaduna & Kano & Katsina & Zamfara & $\begin{array}{l}\text { Fishers } \\
\text { exact test }\end{array}$ & P-value \\
\hline \multicolumn{7}{|c|}{$\begin{array}{l}\text { Presence of fence around } \\
\text { the market }\end{array}$} \\
\hline No & 8 & 14 & 3 & 3 & 44.677 & $<0.001$ \\
\hline Yes & 4 & 1 & 1 & 1 & & \\
\hline \multicolumn{7}{|c|}{$\begin{array}{l}\text { Presence of rodents in the } \\
\text { market }\end{array}$} \\
\hline No & 1 & 2 & 0 & 0 & 42.755 & $<0.001$ \\
\hline Yes & 11 & 13 & 4 & 4 & & \\
\hline \multicolumn{7}{|c|}{ Presence of wild birds } \\
\hline No & 12 & 14 & 3 & 3 & 46.071 & $<0.001$ \\
\hline Yes & 0 & 1 & 1 & 1 & & \\
\hline \multicolumn{7}{|l|}{ Drainage facility } \\
\hline Poor & 5 & 3 & 3 & 2 & 46.401 & $<0.001$ \\
\hline Fair & 2 & 3 & 1 & 1 & & \\
\hline Good & 5 & 9 & 0 & 1 & & \\
\hline \multicolumn{7}{|c|}{ Safe disposal of garbage } \\
\hline No & 1 & 1 & 0 & 0 & 43.350 & $<0.001$ \\
\hline Yes & 11 & 14 & 4 & 4 & & \\
\hline \multicolumn{7}{|c|}{ Availability of clean water } \\
\hline \multirow[t]{2}{*}{ Yes } & 4 & 6 & 0 & 0 & 44.242 & $<0.001$ \\
\hline & 8 & 9 & 4 & 4 & & \\
\hline \multicolumn{7}{|c|}{$\begin{array}{l}\text { Are floors and walls easy } \\
\text { to clean? }\end{array}$} \\
\hline No & 4 & 11 & 1 & 2 & 46.091 & $<0.001$ \\
\hline Yes & 8 & 4 & 3 & 2 & & \\
\hline \multicolumn{7}{|c|}{$\begin{array}{l}\text { Cleaning of equipment } \\
\text { used in processing }\end{array}$} \\
\hline No & 0 & 0 & 0 & 0 & 42.047 & $<0.001$ \\
\hline Yes & 12 & 15 & 4 & 4 & & \\
\hline \multicolumn{7}{|c|}{ If yes, what do you use? } \\
\hline Water & 2 & 4 & 1 & 0 & 42.027 & $<0.001$ \\
\hline Water and detergent & 5 & 6 & 2 & 2 & & \\
\hline $\begin{array}{l}\text { Water,detergent and } \\
\text { disinfectant }\end{array}$ & 5 & 5 & 2 & 2 & & \\
\hline \multicolumn{7}{|l|}{ How often } \\
\hline Daily & 12 & 15 & 4 & 4 & 42.047 & $<0.001$ \\
\hline Weekly & 0 & 0 & 0 & 0 & & \\
\hline Fortnightly & 0 & 0 & 0 & 0 & & \\
\hline
\end{tabular}


Monthly

Use of more than one type

of disinfectant

No

Yes

Enforcement of hands

washing after slaughter

No

Yes

Enforcement of hands

disinfection after slaughter

No

Yes
0

0

0

0

$\begin{array}{llllll}11 & 13 & 4 & 4 & 42.755 & <0.001 \\ 1 & 2 & 0 & 0 & & \end{array}$

$0 \quad 0$

$12 \quad 15$

0

0

$42.047<0.001$

$15 \quad 4$

4

$9 \quad 13$

$13 \quad 4$

4

42.960

$<0.001$

Table 4: Biosecurity Measures/Practices in the Live Bird Markets

\begin{tabular}{lllll}
\hline & High/Good & Moderate/Fair & Low/Poor \\
\hline $\begin{array}{l}\text { Biosecurity } \\
\text { (In LBMs) }\end{array}$ & measure & $6(17 \%)$ & $24(69 \%)$ & $5(14 \%)$ \\
$\begin{array}{l}\text { Biosecurity } \\
\text { (of marketers) }\end{array}$ & Practice & $71(18 \%)$ & $305(76 \%)$ & $24(6 \%)$ \\
\hline
\end{tabular}

Table 5: Disinfection Practices of Live Bird Marketers in North-western States of Nigeria

\begin{tabular}{|c|c|c|c|c|c|c|}
\hline \multicolumn{7}{|c|}{ Frequency } \\
\hline Variable & Kaduna & Kano & Katsina & Zamfara & $\begin{array}{c}\text { Fishers } \\
\text { exact test }\end{array}$ & P-value \\
\hline \multicolumn{7}{|c|}{ Do you clean bird cages? } \\
\hline No & 0 & 1 & 0 & 0 & 2.440 & 1.000 \\
\hline Yes & 137 & 170 & 46 & 46 & & \\
\hline \multicolumn{7}{|c|}{ If yes, what do you use? } \\
\hline Water & 0 & 3 & 0 & 1 & 44.683 & $<0.001$ \\
\hline Water and detergent & 7 & 9 & 0 & 0 & & \\
\hline $\begin{array}{l}\text { Water,detergent and } \\
\text { disinfectant }\end{array}$ & 0 & 23 & 1 & 4 & & \\
\hline Sweeping only & 130 & 135 & 45 & 41 & & \\
\hline \multicolumn{7}{|c|}{ Do you isolate sick birds? } \\
\hline No & 3 & 12 & 0 & 0 & 5.767 & 0.088 \\
\hline Yes & 134 & 158 & 46 & 46 & & \\
\hline \multicolumn{7}{|l|}{$\begin{array}{l}\text { How do you dispose of } \\
\text { dead birds? }\end{array}$} \\
\hline Thrown away & 0 & 0 & 0 & 0 & 46.401 & $<0.001$ \\
\hline Fed to predators & 0 & 0 & 2 & 0 & & \\
\hline Burying in the LBMs & 0 & 4 & 0 & 0 & & \\
\hline Burning & 0 & 30 & 6 & 1 & & \\
\hline Taken away & 137 & 136 & 39 & 45 & & \\
\hline \multicolumn{7}{|c|}{$\begin{array}{l}\text { Do you sell other animal } \\
\text { species? }\end{array}$} \\
\hline No & 113 & 143 & 27 & 34 & 14.740 & 0.002 \\
\hline Yes & 24 & 28 & 19 & 12 & & \\
\hline
\end{tabular}


Table 6: Disinfectants used in some Live Bird Markets of North-western Nigeria

\begin{tabular}{|c|c|c|c|c|c|}
\hline $\mathbf{S} / \mathbf{N}$ & State & LBM & $\begin{array}{l}\text { Disinfectant } \\
\text { (Trade name) }\end{array}$ & Form & Chemical composition \\
\hline 1 & Katsina & Sabuwar kofa & Diskol & Liquid & $\begin{array}{l}\text { Glutaraldehyde,ammonium } \\
\text { chloride, formaldehyde }\end{array}$ \\
\hline 2 & Katsina & Central market & Lysol & Liquid & Methylphenol \\
\hline 3 & Kano & Sharada & Virkon-S & Powder & $\begin{array}{l}\text { Potassium peroxymonosul- fate, } \\
\text { sodium dodecylbenze, } \\
\text { neosulphonate, } \\
\text { sulfamic acid }\end{array}$ \\
\hline 4 & Kano & Sharada & Diskol & Liquid & Glutaraldehyde, ammonium \\
\hline 5 & Kano & Sheka & Нуро & Liquid & Sodium hypochlorite \\
\hline 6 & Kano & Sabon titi & Vinkokill & Liquid & Chlorophenol \\
\hline 7 & Kaduna & Sokoto road & Virkon-S & Powder & Peroxymonosulphate \\
\hline
\end{tabular}

\section{Types of Disinfectants Used in the LBMs}

Table 6 shows LBMs that had disinfectant samples, name of the disinfectant, form, chemical composition and the dilution factor used in the LBM. Majority of the identified disinfectants were in liquid form, with exception of Virkon$\mathrm{S}$ which was in powder form. Kano state had the highest (4) varieties of disinfectant, followed by Katsina state with only two varieties.

\section{DISCUSSION}

All the LBMs were located within high human settlements which poses a health hazard to the humans as they may be exposed to zoonotic diseases of poultry origin. The presence of human population density is a huge compromise to maintenance of biosecurity within the LBMs. This is similar to previous study that indicated there is a strong relationship between human population density and risk of LBMs being virus positive (Henning et al., 2019). The distribution within human settlement was mainly due to their proximity to or within the metropolis commercial markets. This is in agreement with previous study that indicated $64 \%$ of LBMs in Benue state were located and operated within the main market (Abah et al., 2017). These locations will most likely hinder biosecurity measures including proper disinfection and isolation.

The distance between the LBMs within the metropolis also serve as a source of risks. This can be attributed to the fact that wholesales of live birds usually move from one LBM to another, distributing birds which were mostly sourced from backyard farms and weekly village markets. This is similar to study reported in Jarkata, where distance covered during poultry distribution to LBMs increases the chances of LBM being infected (Henning et al., 2019).

The study showed that all the LBM managers were male. This could be attributed to the socio-cultural orientation of the North-Western part of Nigeria, which is contrary to what is obtainable in the southern part of the country where majority were females (AICP, 2008). Eighty (80) percent of the LBMs were not fenced with no control of animal movement. The WHO in 2005 has recommended fencing of markets as a risk reduction measure. The absence of fences and control of movement was probably due to proximity of most LBMs to commercial markets within the metropolis. Rodents were sighted in $91 \%$ of the LBMs, which is far more than $61 \%$ reported in Benue state (Abah et al., 2017). There were less rodents in LBMs from the study in Benue state mainly because $20 \%$ of the bird sellers were using rodenticides. Rodents serve as known carriers of at least 35 diseases and constitute major carriers of poultry pathogens (Adams, 2003). Wild birds have at the least been sighted in $3(9 \%)$ of the LBMs. This has public health implication since the wild birds may serve as a source of infection to other birds (Bridges et al. 2003). Fusaro et al. (2010) reported that in order to effectively control highly pathogenic avian influenza (HPAI) and to prevent future outbreak and rapid spread, there must be minimal contact between wild birds and Live Bird Market chains as well as in between farm transmission. Most of the LBM had fair to poor drainage systems. FAO 2008 reported that most LBMs are lacking basic infrastructures including drainages. This was as a result of improper design and construction of the LBMs, also lack or inadequate maintenance of existing drainages. Very few of the LBMs dispose of garbage properly which is in agreement with FAO (2008) that reported garbage disposal services in LBMs in Nigeria as very poor. It has been reported that some LBMs do bag the wastes and sell to farmers as manure (Aliyu et al., 2020). Previous study by Indriani et al. (2010) has shown that indiscriminate disposal of carcasses and offals in LBMs compromises biosecurity due to infection spread to the waste disposal and sale points. Poor disposal of garbage has also been reported in LBMs in Uganda by Halid et al. (2014). On the contrary, Yee et al. (2008) reported that LBMs in the Western pacific countries were prone to AI outbreak despite proper garbage disposal and regular good sanitary practices. This implies biosecurity should be wholistic and not focus on certain practices. Most of the LBMs have access to clean water, as opposed to previous report by FAO which graded access of the LBMs to clean water as poor. The improved access to clean water was as a result of increased installation of borehole water source, thus replacing the common well water source (40\%) as reported by Aliyu et al., (2020). About half of the LBM's processing area had floors and walls that are easy to clean. This contrary to previous report by FAO (2008), where the floors and walls were not easy to clean. The 
improvement may be due to impact of biosecurity campaign during the AI outbreak in Nigeria. Effective cleaning and disinfection is an integral part of biosecurity at LBM, the present study indicated daily cleaning of equipment, use disinfectants, use detergents alone and use of only water. This is similar to a study in Indonesia that reported $96 \%$ of the LBMs wash poultry area daily, $66 \%$ engage in daily application of detergent or disinfectant, but none use water only (Indriani et al. 2010). The use of water only from this study maybe due to economic reason (saving cost of disinfection) or complacency attitude since there was no disease outbreak. Regular cleaning and disinfection also serve to reduce the risk of introduction and spread of viruses in LBMs (Kung et al., 2003). A study reported that even with the continual entry of infected birds into LBMs, routine cleaning and disinfection serves to decrease the level of environmental contamination (Trock et al., 2008). Very few of the LBMs said they alternate between disinfectants. More than half of the LBMs had a moderate biosecurity level. Very few had high biosecurity level with the rest graded as low.

All the marketers were male contrary to reports from Southern part of the country where women were dominant (AICP, 2008). Majority (55\%) of marketers were between the age group of 20-39 hence mostly youth, an age group responsive to awareness and training. This is similar to a study in Katsina metropolis, where $42 \%$ of the marketers were within the age of 21 - 30years (Aliyu et al., 2020). Significant proportion of the marketers had good level of education, with $46 \%$ of them having had at least secondary school education. This was lower in comparison to $66 \%$ reported in Katsina (Aliyu et al., 2020) and 64\% reported in Kaduna (Oladiran and Kabir, 2015). This could be due to better level of basic education in Kaduna and Katsina states in comparison to other North-western states in Nigeria. However, secondary school education is enough to enable ease of communication and ability to create the required awareness considering the fact that literacy is strongly related to risk cognition and comprehension of public health campaigns (Abdullahi et al., 2010). Majority had wooden cages with only $18.3 \%$ using metal cages which makes it difficult to clean and disinfect as against the recommended use of plastic or metal cages that are easily cleaned (FAO, 2008). The use of cages to keep poultry was also reported in other parts of Nigeria by Ajetomobi and Adepoju in 2010. Almost all of the marketers said they isolate sick birds. This is opposed to previous findings by FAO which reported very poor practice of isolation of sick birds. This disagreement may be due to the impact of public awareness campaign by veterinarians and other stakeholders. Isolation is an integral part of segregation which is one of the fundamental principles of biosecurity. It goes a long way in curtailing spread of infection. Few of the live bird marketers sell other species of animals with some selling more than 2 other species which violates the recommendation of FAO in 2010 which advocates limiting the number of species in a market to reduce the persistence of infection and possibility of crossspecies transmission in the LBM. The sale of multiple species was demand driven, as certain clients do buy or request for turkey, duck, pigeon, Goose, sheep, goat, e.t.c.
Overall, only $18 \%$ of the marketers employ good biosecurity practices while majority were fair and poor. This is less than previous study in Benue state where $70 \%$ of bird sellers had the highest level of biosecurity risky practices following assessment of LBMs (Abah et al., 2017). This could be as a result of the fact that the study in Benue reported overall score for both daily and weekly LBMs. Implementation of biosecurity measures and practices to prevent introduction, replication and spread of infectious agents has often been recommended to reduce the risk of infection or disease within Live Bird Markets (FAO, 2010; Fox, 2012). Ineffective measures may create conditions that favour silent spread of disease agents within the LBMs through such operations (Yupiana et al., 2010).

From the present study, the calculated prevalence as regards the use of disinfectants in LBMs was $17 \%$. This similar to study by Abah et al (2017) who reported that $81.5 \%$ fowl sellers at LBMs do not use disinfectants. However, it is lower than previous report in Nigeria which was $56 \%$ prevalence (Pagani et al., 2008), which could be due to the rigorous control campaign for use of disinfectants in LBMs following the avian influenza outbreaks between 2006 and 2009 in Nigeria. The stakeholders have since been growing more complacent about disinfection in LBMs which has led to the decline in use of disinfectants.

\section{Conclusion.}

The LBMs in metropolis of North-western Nigerian states studied were located within high human population density, thus poses challenges to biosecurity measures and also of public health significance. It is recommended to relocate the LBMs to outskirts of the metropolis and need to step up regulation of poultry trading processes. Escherichia coli was isolated from six LBMs sampled. E. coli was not isolated from any LBM that uses disinfectant sample except one. Hence, live bird marketers should be more pro-active towards disinfection practices by ensuring that they disinfect their premises, cleaning prior to disinfection and proper use of disinfectants.

\section{Acknowledgment}

We sincerely appreciate MacArthur Foundation, Centre of Excellence in Veterinary Epidemiology for funding the research.

\section{Conflict of Interest}

The authors declare that they have no conflict of interest.

\section{Authors Contribution}

HSA carried out the research. MBV designed and supervised the research. KJ designed and supervised the research. AMB participated in sample collection and writing of manuscripts. All authors have read and approved the final manuscript.

\section{REFERENCES}

Abah, H. O., Assam, A. and Abdu, P. A. (2017). Newcastle disease and biosecurity practices in live bird markets in Benue State, Nigeria. Nigerian 
Veterinary Journal, 38(1), 13-25.https://doi.org/10. $\underline{\text { 5897/JVMAH2019.0825 }}$

Abdullahi, M.I., Oguntunde, O. and Habib, A.G. (2010). Knowledge, attitudes, and practices of avian influenza among poultry traders in Nigeria. Internet Journal of Infectious Diseases, 8: 1-8. https://doi.org/10.5580/89e

Adams, J. (2003). Vector: Rats and mice. In; CAMM Poultry, Chapter 10: 1-5. http://www.clemson.edu/extension/livestock/c $\mathrm{amm} / \mathrm{camm}$ _files/dairy/dch10c_04.pdf. Accessed October 12, 2018. 9:- 3 3am.

Ajetomobi, J.O. and Adepoju, A. A. (2010). Avian influenza awareness and profitability of poultry egg production in Oyo State, Nigeria. International Journal of poultry science, 9(2): 183-187. https://dx.doi.org/10.3923/ijps.2010.183.187

Aliyu, M. B. Maikai, B. V. and Magaji, A. A. (2020). Toxoplasma gondii infection and risk factors associated with its spread at live bird markets in Katsina Metropolis, Nigeria. Sokoto Journal of Veterinary Sciences, 18(1), 39-46. https://doi.org/10.4314/sokjvs.v18i1.6

Apostolakos, I., Mughini-Gras, L., Fasolato, L. and Piccirillo, A. (2020). Impact of selective and non-selective media on prevalence and genetic makeup of ESBL/pAmpC-producing Escherichia coli in the broiler production pyramid. Veterinary Microbiology, 240, 108536. https://doi.org/10. 1016/j.vetmic.2019.108536

Augustine, C. Mojaba, D.I. and Igwebuike, J.U. (2010). An assessment of biosecurity status of poultry farms in Mubi zone of Adamawa state, Nigeria. Journal of Agriculture and Veterinary Sciences, 2: 65-67.

Avian Influenza Control Project (AICP) (2008). Development of Live Bird Markets in Nigeria, Avian Influenza Control Project. Consultant Report to Animal Health Component of the Avian Influenza Control and Human Pandemic Preparedness and Response Project, Abuja. 1050.

Awosanya, E.J., (2015). Demographic and management factors associated with biosecurity measure compliance on pig farms in south west Nigeria. Sokoto Journal of Veterinary Sciences, 13(2): 34-41. https://doi.org/10.4314 /sokjvs.v13i2.6

Barcelo, J. and Marco, E. (1998). On farm biosecurity. In: Proceedings of the fifteenth international Pig Veterinary Society Congress. 129-133.

Bridges, C.B., Kuehnert, M.A. and Hall, C.B. (2003). Transmission of Avian influenza: implication for control in Healthcare settings. Clinical Infectious Diseases, 37(8): 1094-1101. DOI:10.1086/378292

Cardona, C., Yee, K. and Carpenter, T. (2009). Are live bird markets reservoirs of avian influenza?. Poultry science, 88(4): 856-859. https://doi.org/10.338 2/ps.2008-00338
Cheesbrough, M. (1981). Medical laboratory manual for tropical countries (Vol. 1). M. Cheesbrough, 14 Bevills Close, Doddington, Cambridgeshire, PE15 OTT. Pp 134-145

David, F. (2015). Increasing the nutrient content of chicken eggs to improve human health. In: Poultry Development Review. FAO, Rome, ISBN 97892-5-108067-2

Food and Agriculture Organization (2008). Biosecurity for Highly Pathogenic Avian Influenza, issues and options. FAO Animal Production and Health Paper No. 165

Food and Agriculture Organization (2010). - Issues and options in developing and transition countries. FAO Animal Production and Health Paper No. 169. Rome, FAO

Food and Agriculture Organization (2015). Biosecurity guide for live poultry markets. FAO Animal Production and Health Guidelines No. 17. Rome, Italy.

Fox, J.Q. (2012). Bio-security in Avian Influenza Control. Retrieved from http://en.engormix.com/MApoultry-industry/health/articles/biosecurityavian-influenza- .Accessed October 12, 2018 at 1:01 pm.

Halid, K., Hannah, K., Achilles, B., Edison, M., Josephine, B., Lukwago., L., Millard, M., Fred, W. and Denis, K.B. (2014). Poor biosecurity in live bird markets in Uganda: A potential risk for highly pathogenic avian influenza disease outbreak in poultry and spread to humans. International Journal of Public health and Epidemiology, 9: 067-074. http://makir.mak.ac .ug/handle/10570/4465

Henning, J., Hesterberg, U. W., Zenal, F., Schoonman, L., Brum, E. and McGrane, J. (2019). Risk factors for $\mathrm{H} 5$ avian influenza virus prevalence on urban live bird markets in Jakarta, IndonesiaEvaluation of long-term environmental surveillance data. PLoS One, 14(5), e0216984. https://doi.org/10.1371/journal.pone.0216984

Indriani, R., Samaan, G., Gultom, A., Loth, L., Indryani, S., Adjid, R., Dharmayanti, N.L.P.I., Weaver, J., Mumford, E., Lokuge, K. and Kelly, P.M. (2010). Environmental sampling for avian influenza virus A (H5N1) in live-bird markets, Indonesia. Emerging Infectious diseases, $16(1$ 2): 1889-1895. https://dx.doi.org/10.3201\%2F eid1612.100402

Kung, N.Y., Guan, Y., Perkins, N.R., Bissett, L., Ellis, T., Sims, L., Morris, R.S., Shortridge, K.F. and Peiris, J.S.M. (2003). The impact of a monthly rest day on avian influenza virus isolation rates in retail live poultry markets in Hong Kong. Avian diseases, 47(s3): 1037-1041. https://doi.org/10.1637/0005-2086-47.s3.1037

Margaret, M.Q. and Paul, K.H. (2015). Cleaning and disinfecting environmental surfaces in health care: Towards an integrated framework for infection and occupational illness prevention. 
American Journal of Infection Control, 43(5): 424-434.

Oladiran, O.G. and Kabir, J. (2015). Evaluation of poultry processing practices, related public health laws and diseases of chickens at slaughter: A pilot study in Kaduna state. Sokoto Journal of Veterinary Sciences, 13(1): 38-47. https://doi.o rg/10.4314/sokjvs.v13i1.6

Olubunmi, G. F., Ismail, A. O., Fatima, A. B. and Folorunso, O. F. (2017). Public health concerns of highly pathogenic avian influenza $\mathrm{H} 5 \mathrm{~N} 1$ endemicity in Africa. Veterinary World, 10(10): 1194-1204. https://dx.doi.org/10.14202\%2Fvetworld.2017. 1194-1204

Qanbari, S., Rubin, C. J., Maqbool, K., Weigend, S., Weigend, A., Geibel, J and Andersson, L. (2019). Genetics of adaptation in modern chicken. PLoS Genetics,15(4), e1007989. https://doi.org/10.1371/journal.pgen.1007989

Pagani, P., Abimiku, Y., and Emeka-Okolie, W. (2008). Assessment of the Nigerian poultry market chain to improve biosecurity. FAO (Nigeria, Consultative Mission on Poultry) Study, 1-65.
Solomon, P., Abolnik, C., Joannis, T.M. and Bisschop, S., (2012). Virulent Newcastle disease virus in Nigeria: identification of a new clade of sublineage $5 \mathrm{f}$ from live-bird markets. Virus genes, 44(1): 98-103. https://doi.org/10.1007/s 11262-011-0678-5

Trock, S.C., Gaeta, M., Gonzalez, A., Pederson, J.C. and Senne, D.A. (2008). Evaluation of routine depopulation, cleaning, and disinfection procedures in the live bird markets, New York. Avian Diseases, 52(1): 160-162. https:// doi.org/10.1637/7980-040607-reg

Yee, K.S., Carpenter, T.E., Mize, S. and Cardona, C.J. (2008). The live bird market system and lowpathogenic avian influenza prevention in southern California. Avian diseases, 52(2): 348-352. https://doi.org/10.1637/8138-101207reg.1

Yupiana, Y., de Vlas, S. J., Adnan, N. M. and Richardus, J.H. (2010). Risk factors of poultry outbreaks and human cases of $\mathrm{H} 5 \mathrm{~N} 1$ avian influenza virus infection in West Java Province, Indonesia. International Journal of Infectious Diseases, 14(9):800-805. https://doi.org/10.1016/j.ijid.2010.03.014 